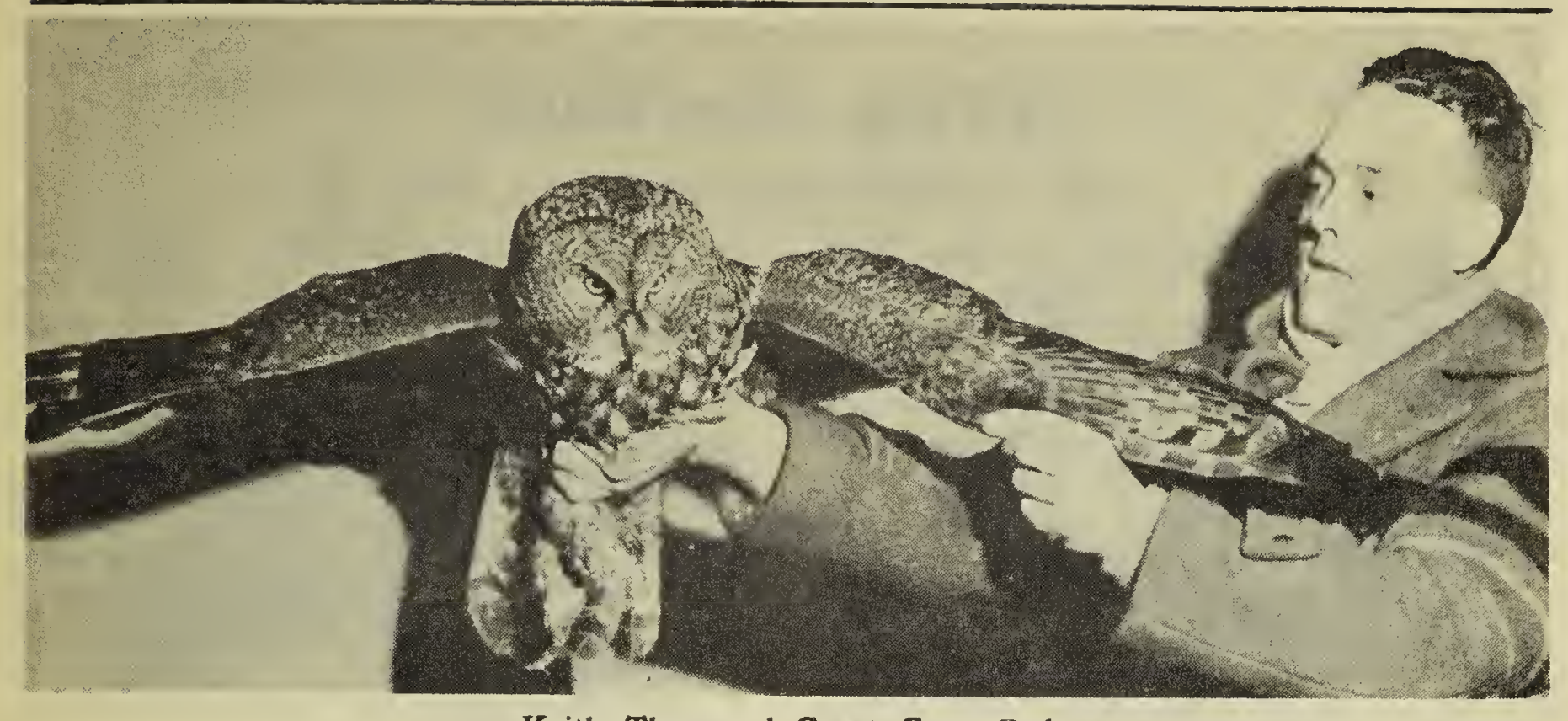

Keith Thue and Great Gray Owl

-Photo courtesy Star-Phoenix

\section{Great Gray Owl Banded at Saskatoon}

By DR. STUART HOUSTON

The stormy evening of January 6th provided the thrill of a lifetime when Keith Thue phoned from the Beaver Creek Game Farm to say that he had trapped a rare Great Gray Owl. It was a superb specimen - perhaps the most beautiful bird I have ever seen and certainly the finest I have banded. Only five had previously been banded in forty years of banding (some 8 million birds) on this continent. Two were banded near Toronto in 1947 and three juveniles have since been banded in Alberta by $\mathrm{Al}$ Oeming. Incidentally, the December 1955 Canadian Geographic is well worth buying for its article by Jones and Oeming on Great Gray Owls and the nest finally found after several years of searching.

The Great Gray is the largest by measurement of our North American Owls - but in weight and actual body size it is smaller than the Horned and Snowy Owls. The difference is in the large head, long wings and tail, and its loose fluffy plumage. This bird was beautifully feathered and appeared well able to withstand any cold that might occur. It was $28^{\prime \prime}$ in length, the wing chord 18" and the wing span 58".

It was too stormy to release it that night, so this magnificent owl spent the night in our basement guest room - ignominiously in a card- board box. Next day it was released unharmed four miles east of Borden, and flew west up the North Saskatchewan.

Owls should never be shot by anyone unfamiliar with their identification; this rare but often rather tame Owl, ordinarily a resident of the northern woods, is an easy prey for any man with a gun. They do venture south, especially during severe winters. If not protected they may easily, like the Whooping Crane, be threatened with extinction. I would like to hear of any other records of the Great Gray Owl in Saskatchewan.

\section{Bird Banding}

By DR. STUART HOUSTON

Our banding expeditions met favorable weather more consistently this year, and between May 1st and December 31st, we banded 1010 individuals of 36 species. The greatest number were colonial birds - 476 Ring-billed Gulls, 154 Doublecrested Cormorants, 134 California Gulls, 82 White Pelicans and 24 Black-crowned Night Herons. Four days in the fall were devoted to constant attention (inspection every 15 minutes) to four mist nets set near the river edge south of Saskatoon, and a total of 86 individuals of 17 species were banded by this means. The backyard traps yielded only 30 individuals. One Goshawk and one Horned Owl were caught at the Beaver Creek Game Farm by Keith (Continued on page 29) 